\title{
The impact of climate oscillations on the surface energy budget over the Greenland Ice Sheet in a changing climate
}

\author{
Tiago Silva ${ }^{1}$, Jakob Abermann ${ }^{1,3}$, Brice Noël ${ }^{2}$, Sonika Shahi ${ }^{1}$, Willem Jan van de Berg ${ }^{2}$, and \\ Wolfgang Schöner ${ }^{1,3}$ \\ ${ }^{1}$ Institute of Geography and Regional Science, Graz University, Austria \\ ${ }^{2}$ Institute for Marine and Atmospheric Research, Utrecht University, Netherlands \\ ${ }^{3}$ Austrian Polar Research Institute, Vienna, Austria
}

Correspondence: Tiago Silva (tiago.ferreira-da-silva@uni-graz.at)

\begin{abstract}
Climate change is particularly strong in Greenland primarily as a result of changes in advection of heat and moisture fluxes from lower latitudes. The atmospheric structures involved influence the surface mass balance and their pattern are largely explained by climate oscillations which describe the internal climate variability. Based on a clustering method, we combine the Greenland Blocking Index and the North Atlantic Oscillation index with the vertically integrated water vapor to analyze interseasonal and regional impacts of the North Atlantic influence on the surface energy components over the Greenland Ice Sheet. In comparison to the reference period (1959-1990), the atmosphere has become warmer and moister during recent decades (1991-2020) for contrasting atmospheric circulation patterns. Particularly in the northern regions, increases in tropospheric water vapor enhance incoming longwave radiation and thus contribute to surface warming. Surface warming is most evident in winter, although its magnitude and spatial extent depend on the prevailing atmospheric configuration. Relative to the reference period, increases in sensible heat flux in the summer ablation zone are found irrespective of the atmospheric circulation pattern. Especially in the northern ablation zone, these are explained by the stronger katabatic winds which are partly driven by the larger surface pressure gradients between the ice/snow-covered surface and adjacent seas, and by the larger temperature gradient between near-surface air and the air above. Increases in net shortwave radiation are mainly connected to high-pressure systems. Whereas in the southern part of Greenland the atmosphere has gotten optical thinner, thus allowing more incoming shortwave radiation to reach the surface, in the northern part the incoming shortwave radiation flux has changed little with respect to the reference period, but the surface albedo decreased due to the expansion of the bare ice area.
\end{abstract}

\section{Introduction}

The Greenland Ice Sheet (GrIS) is located north of the jet stream, with the North Atlantic storm track to the south. The North Atlantic storm track is more active during cold seasons when baroclinicity is strongest. The resulting cyclonic behavior then favor surface mass gains in the south and east of Greenland, whereas planetary wave breaks in the North Atlantic generally contribute to surface mass gains in the western part of the GrIS. Such mechanisms in the North Atlantic often form a highpressure system in the middle troposphere close to Greenland and are described in the literature as Greenland Blocking (e.g. Hanna et al. 2015, Woollings et al. 2018). Both cyclones and blocks are essential for the year-round poleward transport of heat 
and moisture, although the associated thermodynamic and regional impacts vary seasonally (Papritz et al., 2021). The North Atlantic Oscillation (NAO) index and the Greenland Blocking Index (GBI) are widely known and commonly used separately to describe the predominant atmospheric circulation pattern, a pattern which influences the variability of the ice sheet mass change. NAO is based on the surface pressure difference between the semi-permanent Subtropical (Azores) High and the semipermanent Subpolar (Icelandic) Low (Hurrell et al., 2003), and its sign provides insight into the North Atlantic jet stream intensity. The NAO phase may be used to explain most of the heat and moisture transported poleward, as well as temperature and precipitation anomalies over the GrIS (Bjørk et al., 2018). GBI describes the mean geopotential height at 500hPa over Greenland (Hanna et al., 2016). Its index denotes the predominant atmospheric circulation pattern, and it quantifies the strength of heat and moisture transported over the Greenland domain. Hence, GBI correlates particularly well in summer with nearsurface variables and with surface mass balance over the GrIS (Hanna et al., 2013), and since it partially covers the Northeast Atlantic it is highly correlated with the NAO (Hanna et al., 2015). Martineau et al. (2020) studied baroclinic processes in the North Atlantic and reported a vertical tilt on temperature and geopotential height profiles within mature large-scale structures that is caused by the jet stream strength. This implies that under strong jet stream influence (e.g. +NAO), and particularly during the cold season, the 500-hPa geopotential height may not be entirely representative of the near-surface conditions over the GrIS. Therefore, the near-surface impacts, for example, under a positive phase of GBI, which determines the atmospheric conditions in the mid-troposphere, may not necessarily correspond to the near-surface impacts under a negative NAO phase, which is determined by the surface conditions, and vice versa. Although Greenland constitutes a physical barrier in the lowermost troposphere for synoptic structures, the atmosphere is fairly barotropic in summer. The resulting reduction in the equatorto-pole temperature gradient leads to a weakening of the jet stream which then migrates poleward. Hence, we hypothesize that the tilt within large-scale structures may have an impact at different locations and combining NAO (which is based on surface conditions) and GBI (based on $500 \mathrm{hPa}$ conditions) will help to better connect atmospheric variability with near-surface consequences.

The general circulation of the atmosphere over the GrIS plays a major role in surface melt (e.g. Fettweis et al. 2013, Hanna et al. 2013, Hermann et al. 2020, Tedesco et al. 2016; Tedesco and Fettweis 2020). Given the increasingly strong summer blocking conditions observed during recent decades, the air above Greenland has warmed and the GrIS, as well as the peripheral glaciers, have been experiencing mass losses at unprecedented rates since the 1990s (e.g. Broeke et al. 2016 and Shepherd et al. 2020). Recent studies explain that part of the decreased surface mass balance occurs due to snowpack pore saturation in the high-elevation interior (MacFerrin et al., 2019) and in peripheral glaciers (Noël et al., 2017), which has led to less refreezing and thus to enhanced surface meltwater runoff. Moreover, the GrIS albedo feedback (Box et al., 2012) is related to increased rainfall, which augments snow/ice thermal conductivity (Bintanja 2018, Niwano et al. 2021), and in conjunction with the decreased snowfall promotes more solar radiation absorption (Noël et al., 2015), thus assisting the migration of the snow line to higher elevations (e.g. Noël et al. 2019, Ryan et al. 2019). Recent studies that have investigated the role of temperature inversions over the GrIS report that inversions can effectively trap the near-surface moisture (e.g. Niwano et al. 2019 and Shahi et al. 2020) and limit accumulation due to reduced tropospheric mixing (Berkelhammer et al., 2016). Both factors can lead to enhanced surface meltwater runoff, particularly at elevated regions of the GrIS. The surface energy budget (SEB) may 
also be impacted by changes in the atmospheric lapse-rate given the decreasing surface elevation and the observed high air temperatures (e.g. Gregory et al. 2020, Wang et al. 2021).

According to Ruprich-Robert et al. (2017), the North Atlantic sea surface temperature (SST) experienced a cold period from the mid-1960s until the early 1990s, and since then has warmed at a relatively high rate, mainly due to external climate forcing (e.g. solar, volcanic and anthropogenic). In the last two decades, we have experienced the largest positive phase of the Atlantic Multidecadal Variability (+AMV, Cassou et al. 2018), with the highest SST anomalies over the North Atlantic since the late 1930s. Particularly during the cold seasons, the literature implies that ocean-atmosphere interaction impacts the jet stream strength, where +AMV leads to a higher frequency of blocking episodes in the North Atlantic (e.g. Athanasiadis et al. 2020 and Davini et al. 2015). In recent decades, Greenland blocking has been more persistent and extreme, and has increased notably in winter and summer (Barrett et al., 2020). Extreme Greenland blocking not only leads to relatively warm air advection towards Greenland, it also drags warm and saline Atlantic waters poleward, which then reduces new sea ice formation in the Greenland Sea (Chatterjee et al., 2021) and in the Baffin Bay (Myers et al., 2021). Some studies report that the direct impact of decreased sea ice concentration may remain confined to the coastal parts of Greenland (e.g. Pedersen and Christensen 2019 and Ballinger et al. 2021). However, there has also been an increase in the frequency and intensity of cyclones moving poleward (Valkonen et al., 2021), allowing moisture intrusions to enhance rain/surface melt throughout the year at elevated regions (Oltmanns et al., 2019). Thus, as a consequence of the aforementioned factors, we hypothesize that surface impacts have likely changed over time within the same atmospheric configuration.

Here, we explore a cluster method that links climate oscillations and atmospheric water vapor content over the GrIS in order to better capture the combined North Atlantic large-scale influence over the GrIS and to assess differences in the nearsurface impact. Section 2 describes the data analyzed and the methods applied. The Results and Discussion is broken into three subsections. In Section 3.1 we show the inter-annual variability of the North Atlantic large-scale influence over Greenland; in Section 3.2 we describe the inter-seasonal and regional variability of the cluster classification; in Section 3.3 we present inter-seasonal and regional anomalies within the same atmospheric circulation pattern, and we discuss regional changes in the summer ablation zone.

\section{Data and Methods}

\subsection{RACMO2.3p2}

The Regional Atmospheric Climate Model (RACMO) was developed and is maintained by the Royal Netherlands Meteorological Institute (KNMI, van Meijgaard et al. 2008). The polar version RACMO2.3p2 is based on KNMI RACMO2.3 but was developed at the Institute for Marine and Atmospheric research Utrecht (IMAU) with dedicated snow physics (Noël et al. 2018, 2019), and was specifically adapted to model the surface mass balance (SMB) of glacier-covered areas. RACMO2.3p2 is a coupled model (atmospheric and multilayer snow model) and takes account of meltwater percolation, retention, refreezing and runoff (Ettema et al., 2010) making use of the dynamical core of the High-Resolution Limited Area Model (HIRLAM) numerical weather prediction model with the ECMWF IFS cycle CY33r1 (Noël et al., 2019). The earlier ECMWF reanalyses 
https://doi.org/10.5194/tc-2021-388

Preprint. Discussion started: 14 January 2022

(c) Author(s) 2022. CC BY 4.0 License.

(c) (i)

products - ERA40 (Uppala et al., 2005) (1959-1978); ERA-I (1979-1989); and ERA5 (1990-2020) - are used to laterally force the atmospheric model (temperature, specific humidity, pressure, wind speed and direction) with additional input of sea surface temperature and sea-ice cover within the model domain.

The broadband albedo is calculated as dependent on snow grain radius, solar zenith angle, cloud cover and impurities (soot) concentration in the snowpack (Van Angelen et al., 2012). The background bare ice albedo is based on the lowest 5\% albedo values between 2000 and 2015, as retrieved from MODIS product - MOD43. In order to better estimate surface mass changes in rugged ablation zones, and in disconnected peripheral glaciers, RACMO2.3p2 SMB components were statistically downscaled to $1 \mathrm{~km}$ spatial resolution by correcting surface elevation and bare ice albedo biases (Noël et al. 2018, 2019).

RACMO2.3p2, hereafter RACMO2, has been used for many applications over the GrIS with a special focus being placed on surface-atmosphere interaction (e.g. Huai et al. 2020, Lenaerts et al. 2020, Mankoff et al. 2020, Ryan et al. 2019). Recently, the same model version, as part of the GrIS SMB model intercomparison project (GrSMBMIP, Fettweis et al. 2020) was found to provide a realistic representation of the contemporary SMB in the accumulation and ablation zones of the GrIS. Furthermore, Shepherd et al. (2020) and Zou et al. (2020) acknowledged the use of RACMO2 as a complementary tool in estimating GrIS mass changes using satellite data such as GRACE.

\subsection{Quantifying surface ablation}

We have used seasonal (DJF: winter; MAM: spring; JJA: summer; SON: autumn) statistics, in order to characterize the prevailing state of the atmosphere and to avoid potential time lags on the near-surface response due to the heat and moisture transport associated with extreme atmospheric circulation patterns (Barrett et al., 2020) and due to the impact of open water thermal inertia (Hahn et al., 2021; Reusen et al., 2019). Atmospheric variables and surface energy fluxes were seasonally averaged, while surface mass fluxes were seasonally summed. The area averaged for atmospheric variables varies inter-annually and inter-seasonally depending on the extent of mass gain (accumulation zone) and mass loss (ablation zone) over the GrIS and on the peripheral glaciers (Fig. S1).

The energy available for melt (M) was calculated as:

$$
\begin{aligned}
M & =S W \downarrow+S W \uparrow+L W \downarrow+L W \uparrow+S H F+L H F+G H F \\
& =S W_{n e t}+L W_{n e t}+S H F+L H F+G H F
\end{aligned}
$$

Downward and upward short/longwave (SW/LW) fluxes are represented by arrows. SHF, LHF and GHF are the sensible, latent and ground heat fluxes, respectively. All terms represent the snow/ice surface and the energy fluxes received (emitted) by the snowpack are defined as positive (negative). The seasonal surface broadband albedo is the absolute ratio of average SW $\uparrow$ to $S W \downarrow$.

In order to assess potential sources of moisture, the adjacent seas (Fig. S1 in light blue) were divided into four areas (delimited by gray lines): Greenland Sea (Northeast); Iceland/Irminger Sea (Southeast); Labrador Sea (Southwest); and Baffin Bay (Northwest). 
https://doi.org/10.5194/tc-2021-388

Preprint. Discussion started: 14 January 2022

(c) Author(s) 2022. CC BY 4.0 License.

(c) (i)

\subsection{Surface ablation trends and break point detection}

Most studies agree that the pronounced Greenland summer mass loss started in the 1990s (e.g. Mouginot et al. 2019, Hanna et al. 2021, Shepherd et al. 2020). However, the onset of the negative trend varies depending on the time period of each study and on the dataset used. Using the 62 years of data from RACMO2, we divided the dataset into two equally-sized subperiods and explored summer mass loss trends before and after the central splitting year. The non-parametric Mann-Kendall (M-K) trend test is used to assess trend monotonicity and significance on summer surface ablation rates (c.f. 2.2). The slope corresponds to the Theil-Sen (T-S) estimator. The T-S estimator is a robust regression method that does not require the data to be normally distributed and is hence less vulnerable to outliers.

The dataset was divided into two equally-sized sub-periods with varying sub-period length and with one central splitting year. The length of each sub-period varied from 15 to 32 years, with the central splitting year being common to both subperiods. The entire analysis period is considered significant only when the confidence level from the M-K test is higher than (or equal to) $90 \%$ in both sub-periods. Trends in periods exhibiting confidence levels lower than $90 \%$ may still be identical to those exhibiting greater significance levels, but given their high variability they were not considered. The trend analysis was run regionally by dividing the GrIS into its main seven drainage basins (see Fig. S1). The slope of the first $\left(\mathrm{s}_{1}\right)$ and second $\left(\mathrm{s}_{2}\right)$ sub-periods are classified either as increasing (i) or decreasing (d) trends. The combined trend classification of both sub-period slopes is shown by color-coded cells (Fig. S2), whereas the absolute ratio of the sub-period slopes is displayed in Figure 1.

The central splitting year and the length of periods with significant sub-period trends for surface mass loss in summer over the GrIS vary regionally. Significant trends are generally detected for sub-periods with lengths between 15 and 25 years and sub-periods of close to 30 years only occur for regions in the south and west Greenland. The southeast is the only region where significant trends can be found centered in the mid-1980s. In contrast, the most significant trends in the northern regions are found centered in the mid-1990s. There is only one period in the central-west region with a change in the trend signal (Fig. S2), whereas all others show decreasing trends in both sub-periods. 


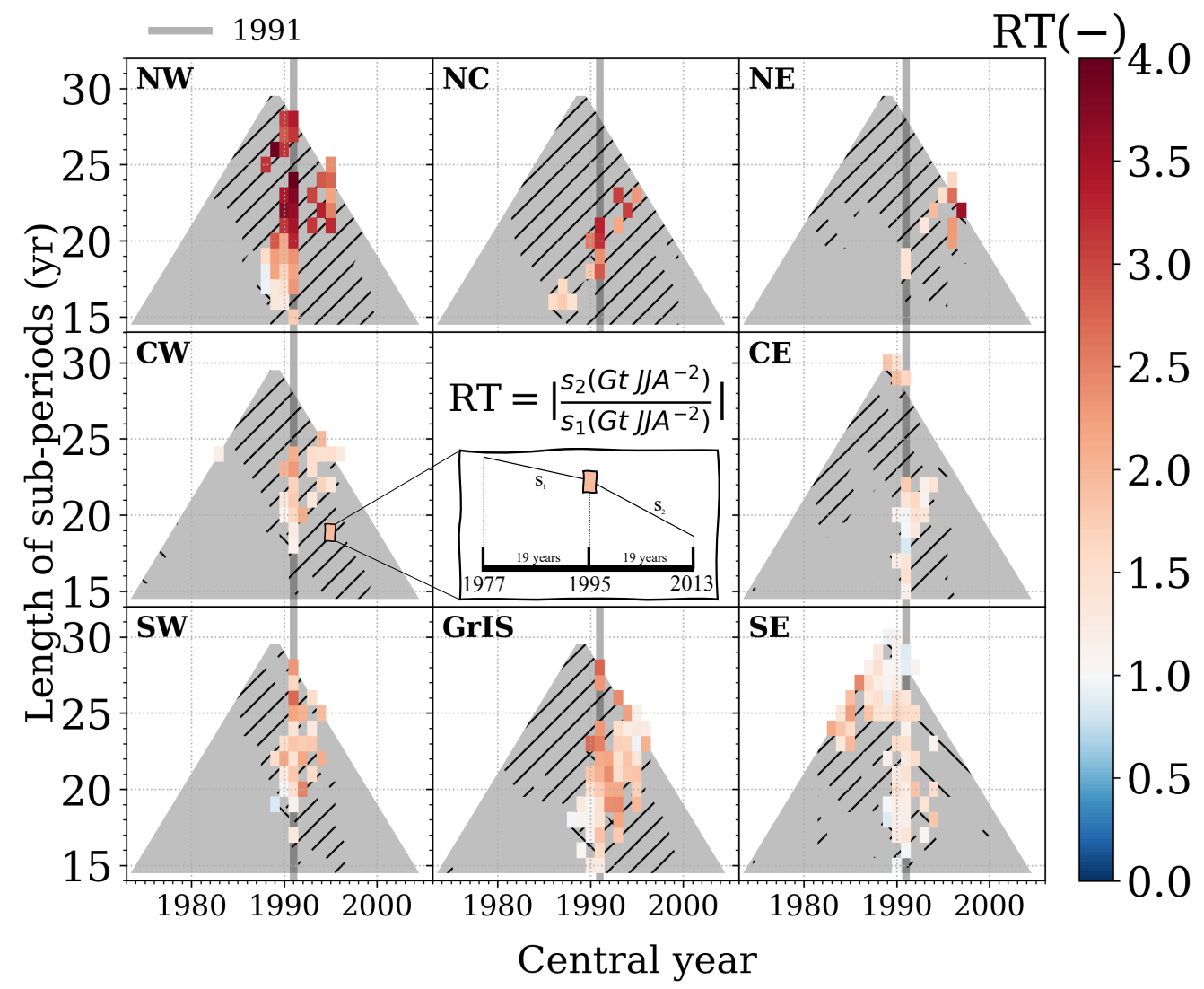

Figure 1. Regional Theil-Sen absolute slope ratio (RT) by splitting the data-set in two equally-sized sub-periods (yaxis) and varying its time-center (x-axis) for the surface integrated ablation rate in summer from RACMO2 between 19592020. Slope ratios are colored when both sub-periods show confidence levels higher than $90 \%$. The remaining significant trends are shown for the first (second) sub-period as left (right) tilted black lines. The gray-shaded area illustrates the domain of all possible periods in the trend analysis. For reference, 1991 is marked with a thick line.

The slope ratios vary depending on the central splitting year and the period length. Major trend shifts are close to 1991 along several period lengths, and 1991 corresponds to the central splitting year with most significant trends amongst regions. Slope ratios increased in magnitude with latitude, especially for periods ranging between 40 and 50 years. In the northern regions, slopes of summer ablation rates during the second sub-period are four times larger than during the first sub-period, while in the southern regions, more specifically in the southeast, the first sub-period slopes are only occasionally larger $(\mathrm{RT}<1)$.

Based on this assessment, we use 1991 as the year to split the period 1959-2020 into two sub-periods and to explore interseasonality of atmospheric variables as a function of climate oscillations. The same year was also used in recent literature (e.g. Broeke et al. 2016; Noël et al. 2019; and Hanna et al. 2021) for trend analysis and will hence allow for direct comparison of results.

\subsection{Combination of climate oscillations}

NAO and GBI data were obtained from the NCEP/CPC and the PSL/ESRL, respectively. Both climate oscillations were seasonally standardized relative to the period 1950-2000.

In order to understand the extent to which NAO and GBI are related to or influenced by other climatic indices, data on the Arctic Oscillation (AO) and on the Atlantic Multidecadal Variability (AMV) were obtained from CPC/NCEP and PSL/ESRL, 
respectively, and analyzed for the period 1959-2019. The non-parametric Spearman correlation coefficient $\left(\mathrm{r}_{\mathrm{S}}\right)$ was calculated in order to quantify the relationships (strength and direction) between the variables. Seasonal GBI and NAO are highly and negatively correlated. However, in summer GBI correlates better $(-0.8)$ with Greenland SMB rates than NAO (0.7) with a 99.9\% confidence level. The GBI is also influenced by other atmospheric/oceanic patterns and correlates best with AO in winter $(-0.9)$ while NAO correlates with AO better during the remainder of the year (-0.9), and AMV only shows a significant positive correlation with GBI during the summer (0.5). Cross-correlation was applied to the climate indices and the entire GrIS surface mass fluxes in order to assess potential links associated with the near-surface climate, triggered by the atmospheric circulation in preceding seasons. However, no substantial improvements in correlation were found. This suggests that there is no relevant time-lag response between seasonal GrIS surface mass fluxes and the predominant atmospheric circulation pattern prevailing in the preceding seasons.

The composite analysis of one climate oscillation alone may not be enough to understand the atmospheric circulation influence on surface processes caused by the other. In addition, the inclusion of GrIS integrated water vapor (IWV) in the classification can also reinforce the role of the two climate oscillations with respect to heat and moisture advection towards Greenland. Based on 3 clusters/classifications (positive, neutral and negative) defined in advance, the 3 seasonal variables used (NAO, GBI, GrIS IWV) are represented by points in a 3-dimensional space for a period of 62 years. As an initial condition, 3 random points are selected in space to represent the center of each cluster. The 3-dimensional Euclidian distances between the 62 points and the center of the 3 random clusters are calculated. Points are classified individually based on their distance to the center of the closest cluster. The center of the 3 clusters shifts iteratively by the mean distances of all points within its own cluster. The best possible grouping is achieved by selecting the minimum calculated sum of squares of the distances between grouped points and the mean center of each group. The k-means clustering method is then repeated seasonally. The resulting clustering classification can be seen in Figure S3. 
https://doi.org/10.5194/tc-2021-388

Preprint. Discussion started: 14 January 2022

(c) Author(s) 2022. CC BY 4.0 License.

\section{Results and Discussion}

\subsection{The influence of the North Atlantic over Greenland}

The newly derived cluster classification is considered as the influence of the North Atlantic over Greenland and is hereafter referred to as NAG. The positive phase of NAG is connected to the anomalously elevated geopotential height at $500 \mathrm{hPa}$ level (+GBI) as well as high IWV, and to the anomalously negative pressure difference between the semi-persistent Azores high and the semi-persistent Icelandic low (-NAO).

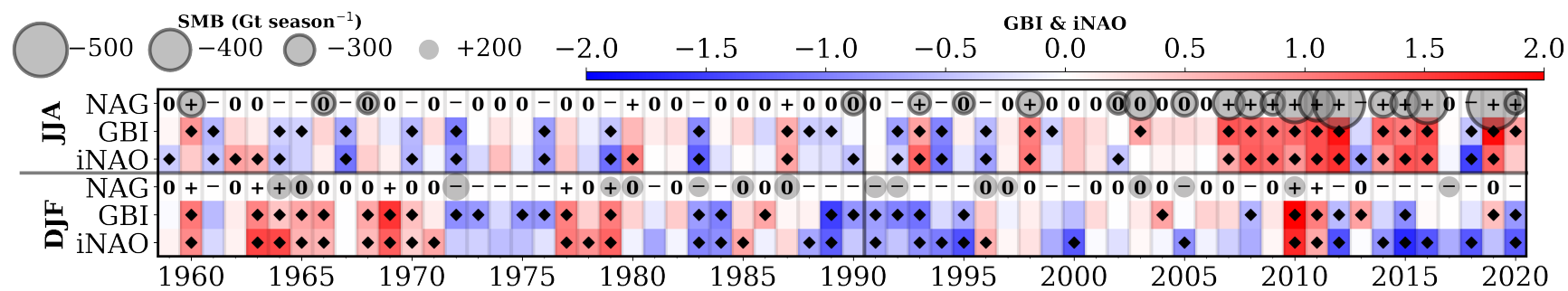

Figure 2. Time-series of seasonal GBI, signal inverted NAO (iNAO) and NAG classification. GBI and iNAO phase are color-coded and NAG phase is coded by symbols - positive (+); neutral (0); and negative (-) phase. The negative (positive) GBI and iNAO phase based on the $25^{\text {th }}$ $\left(75^{\text {th }}\right)$ percentiles are illustrated as diamonds. Seasonally accumulated surface mass balance (SMB) for absolute quantities larger than 200 Gt season ${ }^{-1}$ is sized accordingly. An SMB deficit is marked by a dark circle around the bubble. For reference, 1991 is highlighted.

Owing to the high variability of the data no connection could be found between NAO and GBI within winter clusters. This was also mentioned by Hanna et al. (2015) and serves to point that the influences exerted by NAO and GBI may differ (Fig. S3). Nevertheless, for autumn, a significant correlation is revealed between NAO and GBI for the -NAG cluster, while spring and summer show correlations for the positive and neutral clusters. Moreover, the $95^{\text {th }}$ percentile of IWV is mainly connected to positive NAG phases in summer and winter, but high IWV values also occurred on a few extraordinary occasions in spring and autumn under neutral phases. The inter-seasonal geopotential height anomaly with respect to the climatology (1959-2000) at $925 \mathrm{hPa}$ and $500 \mathrm{hPa}$ is shown in Figure S4. In spite of the fact that the typical life cycle of the NAO phase lasts about two weeks (Feldstein, 2003), the vertical tilting structure described by Martineau et al. (2020) remains within seasonal composites. The NAG cluster classification is shown in Figure 2, alongside seasonal GBI and signal inverted NAO (iNAO, only here used

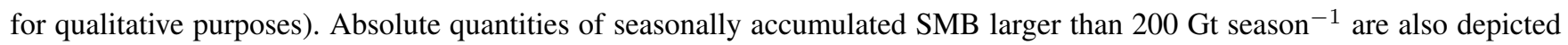
in Figure 2. The seasonal SMB indicates surface mass changes over both the GrIS and the peripheral glaciers. Strongest mass losses coincide with summer, and are mostly connected to +NAG after 1991. Whereas in summer and autumn +NAG contributes the least to surface accumulation, in winter +NAG frequently contributes the most to surface accumulation. In spring, when the equator-to-pole temperature contrast is the strongest, opposite NAG phases can contribute equally to seasonal accumulation in the SMB. A more comprehensive view of seasonal and spatial integrated surface mass balance is seen in Figure S5. 


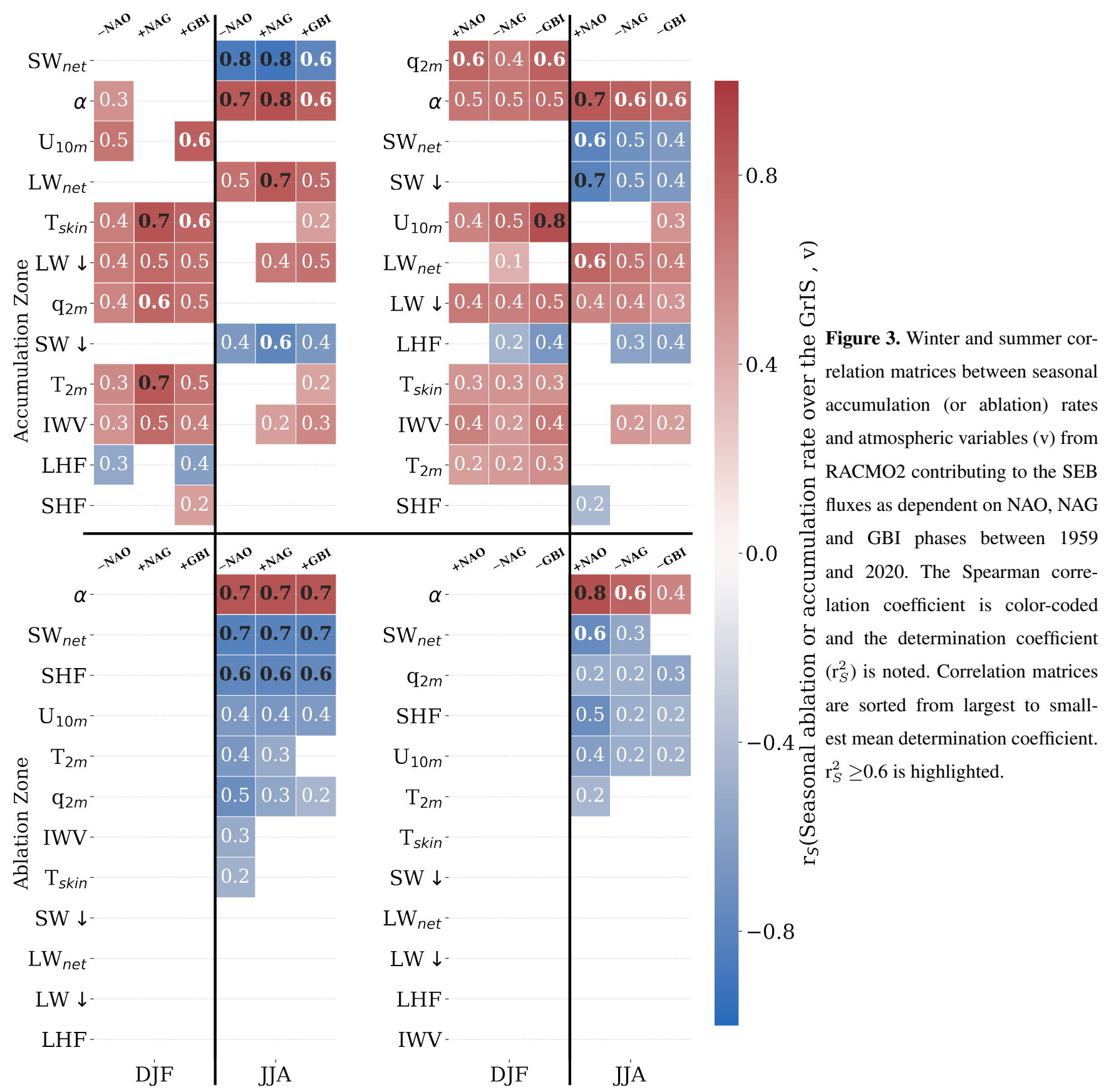

Correlations between seasonal accumulation (or ablation) rates and atmospheric variables as dependent on the NAO, NAG and GBI phase can be found in Figure 3. Under blocking conditions, NAG shows higher correlations between seasonal surface mass balance rates and atmospheric variables than NAO and GBI over the GrIS accumulation zone in winter and summer, whereas in summer, such correlations for the ablation zone are similar for NAO, NAG and GBI. GBI and NAO generally show 
https://doi.org/10.5194/tc-2021-388

Preprint. Discussion started: 14 January 2022

(c) Author(s) 2022. CC BY 4.0 License.

(c) (1)

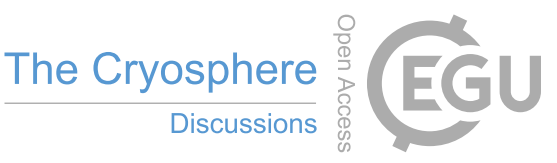

higher correlations between seasonal surface mass balance rates and atmospheric variables in spring and autumn than do NAG, except with respect to the autumn ablation zone where the opposite is found (Fig. S6). Under neutral phases and under strong jet stream conditions, there are only relatively small differences in NAO, NAG and GBI concerning the correlations between surface mass balance rates and atmospheric variables.

\subsection{Inter-seasonal NAG climatology}

Spatial and inter-seasonal anomalies under contrasting NAG phases with respect to the 0NAG are illustrated in Figure 4 (and Fig. S7) for IWV, $L W \downarrow, \mathrm{q}_{2 \mathrm{~m}}$ and $\mathrm{T}_{\text {skin. }}$. Seasonal $\mathrm{T}_{\text {skin }}$ and $\mathrm{T}_{2 \mathrm{~m}}$ are highly and positively correlated $\left(\mathrm{r}_{\mathrm{S}}>0.9\right)$ in the ablation and accumulation zones for contrasting NAG phases. Differences in their correlation are little and only found close to the ice-sheet margins in summer where the snow/ice surface is physically constrained to $273.15 \mathrm{~K}$ (not shown). Moreover, increases in seasonal $\mathrm{T}_{2 \mathrm{~m}}$ are accompanied by exponential increases in $\mathrm{q}_{2 \mathrm{~m}}$. Spatial and inter-seasonal anomalies for $\mathrm{U}_{10 \mathrm{~m}}$, SHF, LHF, and (ice+liquid water) cloud content are shown in Figure S8.

High IWV occurs mainly in the coastal area and rapidly decreases towards the elevated interior regardless of the NAG phase (Fig. 4a). Major IWV differences are found in all seasons in West Greenland where meridional heat and moisture advection is promoted by + NAG. In winter and summer, the LW $\downarrow$ signal (Fig. 4b) agrees with IWV anomalies for both phases. However, decreases in LW $\downarrow$ are not always related to anomalies in IWV. IWV differs the most from $\mathrm{q}_{2 \mathrm{~m}}$ in summer close to the equilibrium line where the largest amounts of $\mathrm{q}_{2 \mathrm{~m}}$ are found due to the expansion of the melting area under +NAG. This is particularly seen along the west of Greenland. Also, the northeast interior experiences $\mathrm{q}_{2 \mathrm{~m}}$ increases which are as high as those in the ablation area. 
https://doi.org/10.5194/tc-2021-388

Preprint. Discussion started: 14 January 2022

(c) Author(s) 2022. CC BY 4.0 License.
Figure 4. Seasonal and spatial anomalies for (a) integrated water vapor (IWV), (b) incoming longwave radiation at the surface (LW $\downarrow$ ), (c) specific humidity at $2 \mathrm{~m}\left(\mathrm{q}_{2 \mathrm{~m}}\right)$ and (d) skin temperature $\left(\mathrm{T}_{\text {skin }}\right)$ for opposite NAG phases with respect to the neutral phase $(\overline{+(-) \mathrm{NAG}}-\overline{\mathrm{ONAG}})$ between 1959 and 2020. The percentage of each NAG phase used to produce composites is indicated as a subtitle in each season. For reference, Summit and South Dome are marked with big and small black triangles, respectively. Stippled regions indicate areas with a confidence level greater than $90 \%$ (based on the Wilcoxon rank-sum statistic test for unpaired sets). a)
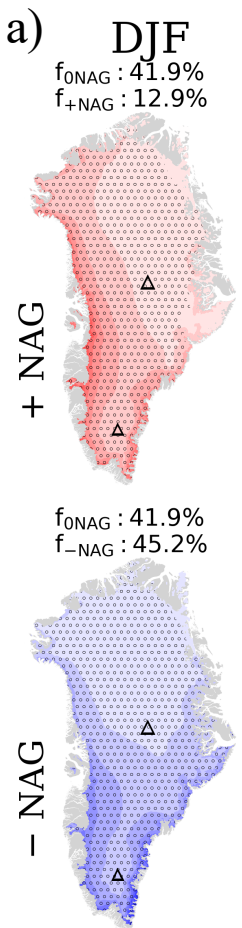

c)
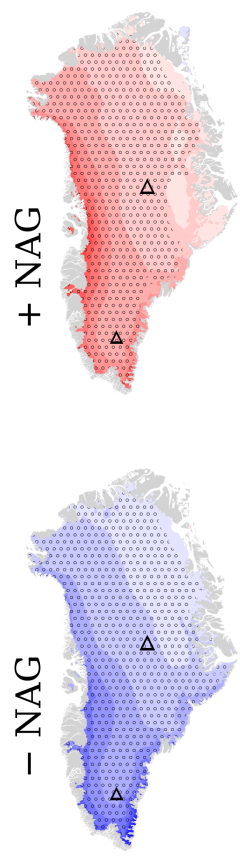

b) $\mathrm{DJF}$

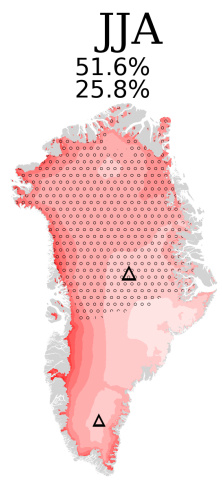

IWV

(mm)

1.0

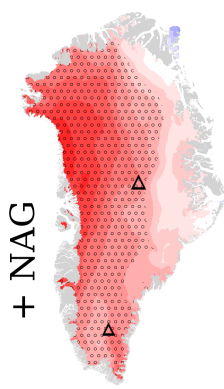

0.0

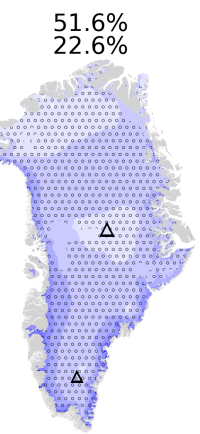

(0.0

$-0.5$

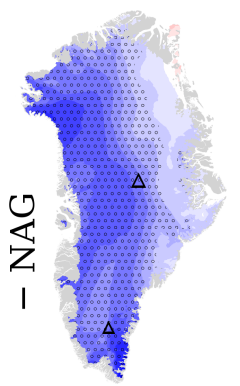

$-1.0$

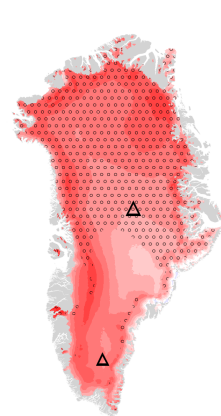

$\mathbf{q}_{2 \mathrm{~m}}$

$\left(\mathrm{g} \mathrm{kg}^{-1}\right)$

\section{d)}
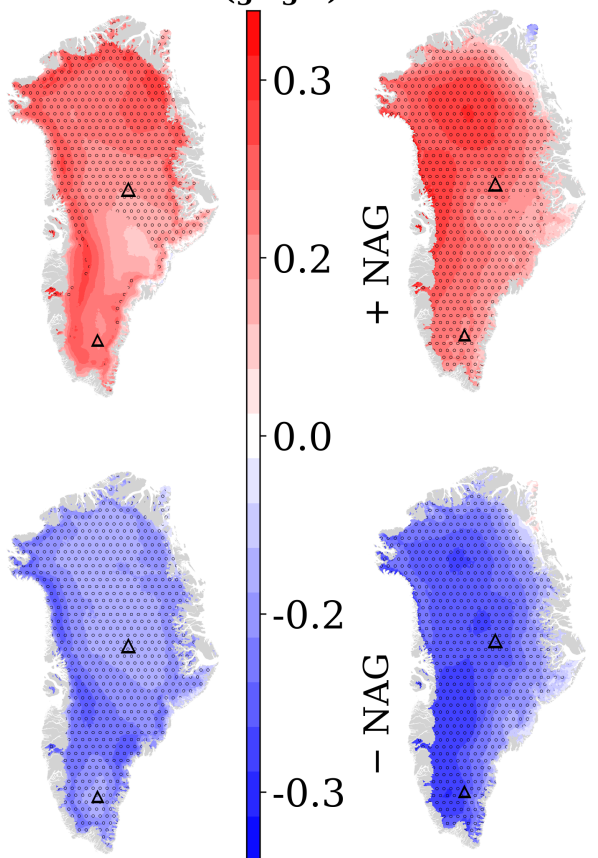

$-0.0$

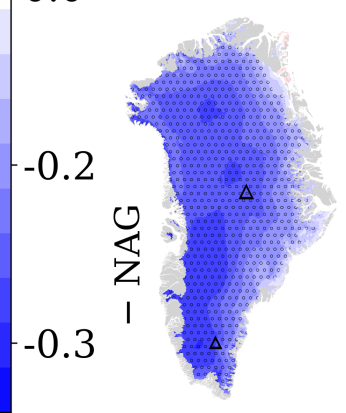

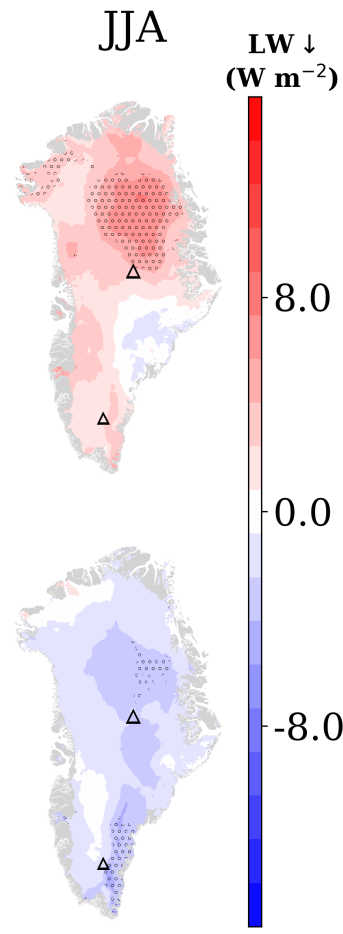

$\mathbf{T}_{\text {skin }}$

$-4.0$

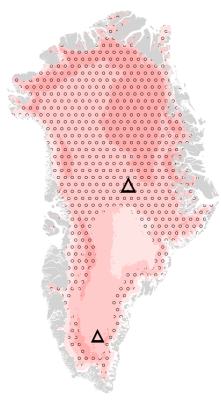

$-2.0$

0.0

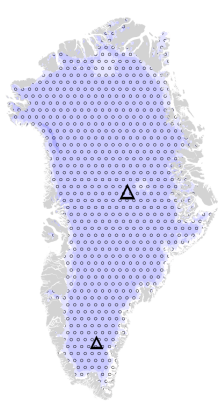


The largest $\mathrm{T}_{\text {skin }}$ anomalies (Fig. 4d) are found in winter, more specifically in the north of Greenland, where the +NAG is up to $4 \mathrm{~K}$ warmer than 0NAG. Positive anomalies in summer are spread around the GrIS and extend to the entire northern region.

The katabatic winds are stronger in winter during +NAG, whereas in the negative NAG phase they are weaker (Fig. S8a). Under the -NAG, the barrier winds in the southeast become stronger as a result of orography-cyclone interaction, from the Denmark Strait to the southernmost tip of Greenland. Also, due to steep surface the near-surface winds at this location are strong the entire year, whereas most of the katabatic flow around the GrIS is weaker with respect to the 0NAG.

SHF is mostly driven by the high near-surface wind speeds, independently of the NAG, with the exception of the southern ablation zone during summer under $+\mathrm{NAG}$, where winds decrease but the near-surface temperature and specific humidity gradient increase (Fig. S8b, c), resulting in positive SHF and LHF anomalies with respect to 0NAG. Particularly in winter during the +NAG phase, the strong katabatic winds associated with the high SHF heat the surface and prevent surface cooling as much as is found in the other NAG phases. In contrast, the katabatic wind under the +NAG phase redistributes the nearsurface water vapor and reduces the LHF for most of the year. Except in the southeast, the LHF becomes less negative under -NAG due to a weakening of the katabatic flow all over the GrIS. Whereas the liquid water within clouds (LWP) lie mainly along the coastline, the ice content within the clouds (IWP) spreads further inland, exhibiting opposite patterns in winter and summer: +NAG(-NAG) in winter promotes more IWP at the Northwest (Northeast), while in summer increases (decreases) in IWP are favored over the whole of Greenland under $-\mathrm{NAG}(+\mathrm{NAG})$.

The $\mathrm{RH}_{2 \mathrm{~m}}$ is relatively high over most of the ice-sheet during +NAG with a highly positive correlation with IWV. Moreover, $\mathrm{RH}_{2 \mathrm{~m}}$ in the western ablation zone varies little in opposite NAG phases. The highest values are found in winter for most of the western and northern regions. However, in summer under +NAG, the southern GrIS is generally less saturated than the northern part. Values of high $\mathrm{RH}_{2 \mathrm{~m}}$ over the northern part of the GrIS are associated with high water vapor amounts in the lower-troposhere that promote low cloud/fog conditions and comparatively elevated levels of LW $\downarrow$. In spite of the relatively small but highly radiative cloud content in this region, the $\mathrm{SW} \downarrow$ is only partly attenuated. Moreover, a small increase in LWP compensates a small decrease in IWP, and hence the cloud content varies little under +NAG relative to 0NAG over the same region.

\subsection{Inter-seasonal NAG variability}

\subsubsection{Seasonal and spatial anomalies}

For each NAG phase, Figure 5 (and Fig. S9) shows the seasonal 1991-2020 anomalies based on the 1959-1990 period. The respective composite for GBI and NAO are shown in Figure S10 and S11. The proportion of years before and after 1991 in each composite is stated at the top of the Figure 5a. An unchanged surface-atmosphere interaction under a specific atmospheric configuration pattern would lead to anomalies close to zero. However, we find positive significant deviations over the GrIS and adjacent seas in most seasons for all NAG phases.

The amount of water vapor in the atmosphere (Fig. 5a) has significantly increased in the northern part of Greenland (Fig. S7a). Significant increases of IWV are also found in winter and summer in the western part of Greenland, partly related to 
a) $\mathrm{DJF}$

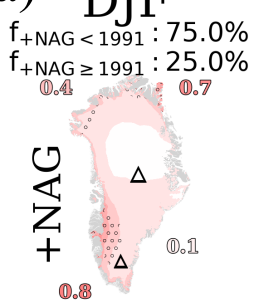

$f_{\text {ONAG }}<1991: 53.8 \%$

$\mathrm{f}_{\text {ONAG }} \geq 1991: 46.2 \%$

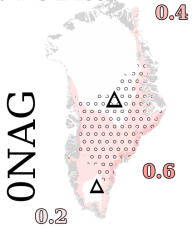

$f_{-N A G}<1991: 42.9 \%$

$\mathrm{f}_{-\mathrm{NAG}} \geq 1991: 57.1 \%$

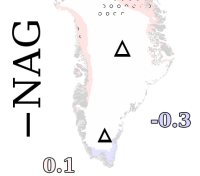

c)
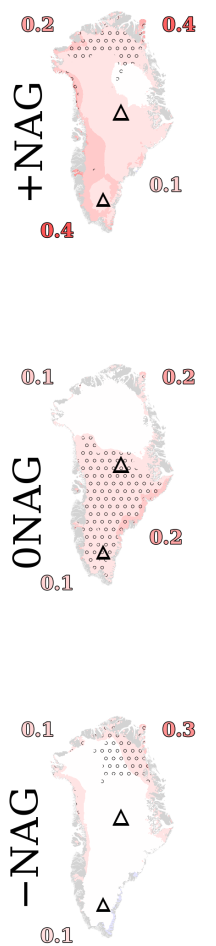

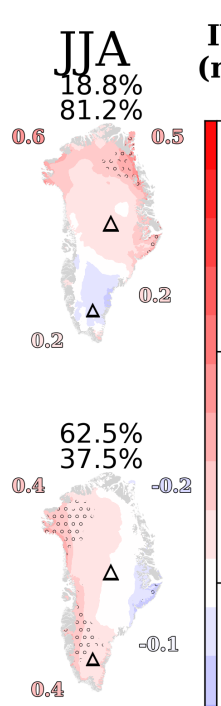

IWV (mm)

1.6

0.8

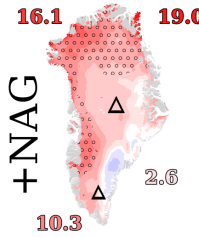

b) $\mathrm{DJF}$
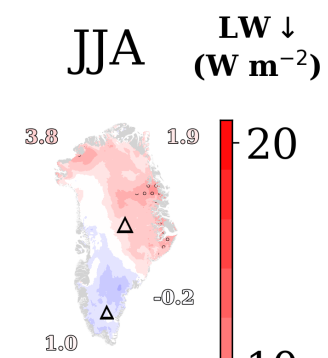

10
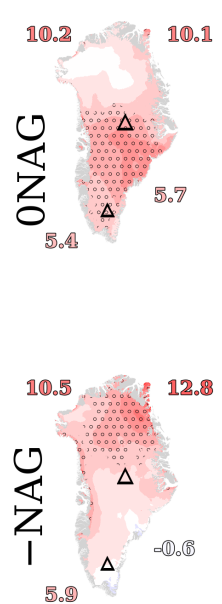

d)

$\mathbf{q}_{2 m}$
$\left(\mathbf{g ~ k g}^{-1}\right)$
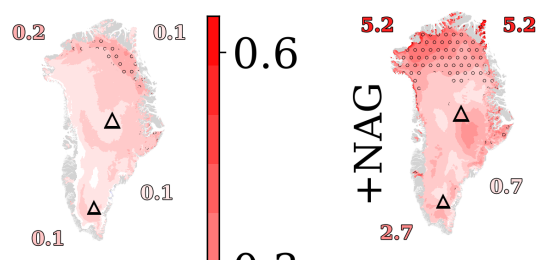

0.3

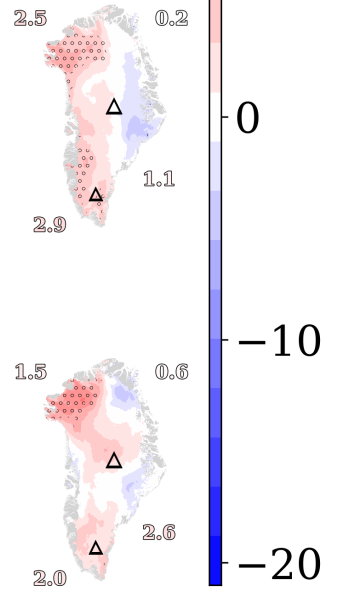

$-10$

$\mathbf{T}_{\text {skin }}$

(K)

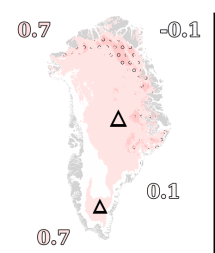

5.0

Figure 5. Seasonal and spatial anomalies between the second (1991-2020) and the first (1959-1990) sub-period composite for (a) integrated water vapor, (b) incoming longwave radiation reaching the surface, (c) near-surface specific humidity, and (d) skin temperature as dependent on the NAG phase. The percentage of the NAG phase in each sub-period is indicated for each season. For reference, Summit and South Dome are marked as big and small triangles, respectively. Stippled regions indicate areas with a confidence level greater than $90 \%$ (based on the Wilcoxon rank-sum statistic test for unpaired sets). Differences between composites over the adjacent seas are

2.5 also shown as colored numbers (Baffin Bay: upper left; Greenland Sea: upper right; Irminger Sea (lower right) and Labrador Sea (lower left). 
increases of IWP and general atmospheric warming. In recent decades, especially during cold seasons, negative NAG phases advect more moisture to northeast Greenland than in the past. The combined warm and moist air has enhanced LW $\downarrow$ in the region. In the interior, the relative warm but dry atmosphere explains the increase in LW $\downarrow$. In summer, moisture increased poleward along the west coast in all NAG phases. The major significant increases in IWV during summer occur in the north under +NAG and along the west coast under 0NAG. Over the adjacent seas, the largest anomaly in IWV (nearly $1 \mathrm{~mm}$ ) is found in autumn under ONAG in the northeast (Fig. S9). Also, similar IWV increases in winter during +NAG are found in the northeast and southwest.

The decreasing summer cloud cover trend in the southwest reported by Lim et al. (2016) and Hofer et al. (2017) is consistent with the negative anomaly in IWV found under +NAG. Decreases in water vapor in the atmosphere extend from spring until autumn (Fig. S9). However, these are not significantly different from those in the reference period under the same atmospheric configuration. An increase in $\mathrm{SW}_{n e t}$ can be seen over the same southern regions as a consequence of more incoming SW radiation. Since the adjacent southern seas of Greenland show an opposite change, the inland decreased IWV has to be driven by regional effects. The light winds, the incoming SW radiation and $\mathrm{q}_{2 \mathrm{~m}}$ increase at the surface point to subsidence in the region. In the southern regions during summer, the surface comprises more $\mathrm{q}_{2 \mathrm{~m}}$ for the period 1991-2020 than during the reference period (Fig. 5c), a consequence of the surface-based inversions promoted by subsidence and surface melt. This is in line with the findings of Niwano et al. (2019) and Shahi et al. (2020). Despite the increase in IWV over the northern regions, which is not related to changes in cloud water content, the $\mathrm{SW}_{\text {net }}$ increased the most.

In summer, the increase in the IWV is mainly associated with the increase of water vapor in the lower-troposphere, which translates into similar LW $\downarrow$ anomaly patterns. The increased cloud water content along the western coast also contributes to the increase in $\mathrm{LW} \downarrow$.

The largest $\mathrm{T}_{\text {skin }}$ anomaly is found in winter under +NAG in the northern part of Greenland, where a similar temperature increase (nearly $5 \mathrm{~K}$ ) is also found over the adjacent northern seas. For other NAG phases and regions, $\mathrm{T}_{\text {skin }}$ anomalies over land are larger than over the adjacent seas. Except in the southeast where the SHF explains the near-surface warming, the $\mathrm{T}_{\text {skin }}$ positive anomaly during winter is mainly a result of the low-troposphere warming (Fig $5 \mathrm{~b}, \mathrm{~d}$ ). The contribution of more water vapor in the atmosphere to the surface warming in winter is particularly strong under +NAG and otherwise confined to southern parts and coastal areas. This $\mathrm{T}_{\text {skin }}$ warming has the potential to affect the snow metamorphosis, and hence a thinner snow layer can more efficiently and more quickly expose darker layers in the following summer regardless of the prevailing atmospheric circulation pattern and hence accelerate surface mass loss. Summer shows the lowest $\mathrm{T}_{\text {skin }}$ anomalies for all NAG phases. Nevertheless, significant differences in $\mathrm{T}_{\text {skin }}$ are found in the north. In fact, the north of Greenland warmed in all NAG phases. $T_{\text {skin }}$ anomalies extend to the west of Greenland and to the entire south under 0NAG. Despite the fact that the $T_{\text {skin }}$ is physically limited to $273.15 \mathrm{~K}$, large areas show an increase in $\mathrm{T}_{\text {skin }}$, and this accords with proportional increases in $\mathrm{T}_{2 \mathrm{~m}}$. With respect to the reference period, only spring under -NAG is found to exhibit surface cooling in recent decades. However, for the northern adjacent seas, the opposite is found to be the case (Fig. S9).

290 Figure S10 and S11 show regional anomalies within the atmospheric configuration of GBI and NAO, respectively. In spite of the fact that GBI and NAO are highly negatively correlated in summer, they show distinct results when analyzed separately. 
This points to temporal changes in one climate oscillation index that are not accounted by the other, and vice versa. The exceptionally high summer GBI values in recent decades have led to an increase in the 1959-2020 percentile threshold, and thus prevents the detection of similar index magnitudes before 1991. The same explanation holds for the rest of the year, as the NAO-GBI correlation is relatively weak.

Decreases in IWV and $\mathrm{q}_{2 \mathrm{~m}}$ are found in summer in the southwest under +GBI. In contrast, IWV and $\mathrm{q}_{2 \mathrm{~m}}$ values under -NAO exhibit increases in comparison to the 1959-1990 period. This illustrates the crucial role of NAO advecting heat and moisture towards high latitudes, an effect that is not fully captured by GBI at the $75^{\text {th }}$ percentile threshold. In spite of the increasing IWV in summer during -NAO, small increases in $\mathrm{SW} \downarrow$ are also found under +GBI and -NAO over the northern part of Greenland. During winter, all variables in our analysis show larger differences for NAO than for GBI. Particularly for IWV and $\mathrm{q}_{2 \mathrm{~m}}$, only relatively small differences are found for GBI and significant ones are only found under NAO. However, both climate oscillations register positive anomalies in $\mathrm{LW} \downarrow$ and $\mathrm{T}_{\text {skin }}$. Major warming is found under NAO, reaching up to $5 \mathrm{~K}$ in the GrIS interior, whereas the highest temperature increase for GBI anomalies is found in autumn under the negative phase. However, increases in temperature are found in the northern part regardless of the climate oscillation or phase. Warming anomalies over the adjacent seas are larger under -NAO, but over the northern GrIS the warming is similar for contrasting NAO phases. Both climate oscillations (-GBI and $+\mathrm{NAO}$ ) are in agreement with $-\mathrm{NAG}$ concerning the anomalously cold spring.

\subsubsection{SEB changes over the summer ablation zone}

Figure 6 shows regional changes in surface energy components in the summer ablation zone as dependent on the NAG phase. Regional changes in $\mathrm{T}_{2 \mathrm{~m}}, \mathrm{~T}_{\text {skin }}, \Delta \mathrm{T}$, IWV, $\mathrm{U}_{10 \mathrm{~m}}$ and individual radiation fluxes are shown in Figure $\mathrm{S} 12$. Most regions show an increase in SHF regardless of the NAG phase. The SHF increase is linked to the intensification of the winds and the strengthening of the near-surface temperature gradient (Fig. S12a). The near-surface temperature gradient is enhanced by the larger increase of the air temperature than the temperature of the melting snow/ice surface, whereas the wind speed, as of the increase in surface pressure gradient, is by the melting snow/ice surface. Particularly in the northern regions, one factor that can be contributing to the increase in summer wind speed is the decrease in ice in the neighboring seas, a change among composites which occurs irrespective of the prevailing atmospheric circulation pattern.

$\mathrm{SW}_{n e t}$ has also increased in both the northern and southern regions, and is commonly associated with +NAG. Whereas in the south $\mathrm{SW}_{n e t}$ increased due to more $\mathrm{SW} \downarrow$ as a result of an optical thin atmosphere (Hofer et al., 2017; Lim et al., 2016), in the north the increase is due to a darker surface as a consequence of the expansion of the bare ice area (Noël et al., 2019). $\mathrm{SHF}$ and $\mathrm{SW}_{\text {net }}$ are the largest changes on SEB fluxes in most regions regardless of the NAG phase. These two variables have been reported as being the main melt drivers in recent decades (Wang et al., 2021). Solar radiation changes in the south are accompanied by decreases in IWV, whereas in the north, they are associated with decreases in SW $\uparrow$. In spite of the fact of reduced $\mathrm{LW} \downarrow, \mathrm{LW}_{\text {net }}$ generally becomes more negative, which points to surface warming. The largest changes in temperature, IWV, wind-speed and in energy available to melt in the summer ablation zone occurred under ONAG, especially over the southern part of Greenland. 
https://doi.org/10.5194/tc-2021-388

Preprint. Discussion started: 14 January 2022

(c) Author(s) 2022. CC BY 4.0 License.

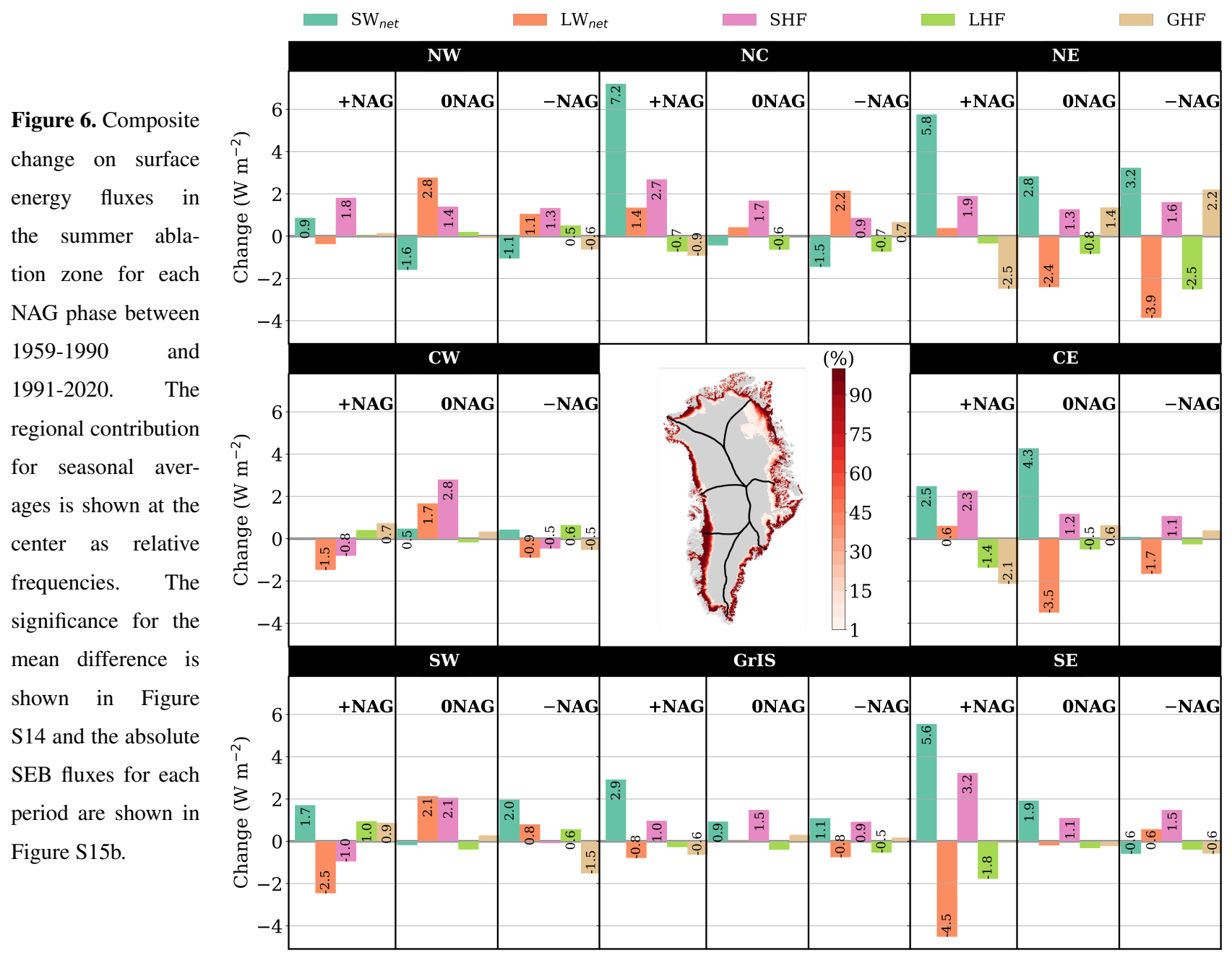

Apart from a few isolated areas in the north under +NAG, there is not a strong signal in GHF. Particularly in the southeast, GHF used to contribute more to SEB than SHF, but in recent decades the role of SHF on SEB has become higher than that of GHF. In spite of the wind speed increase over large areas, we find small differences in LHF (Fig. S15b) under +NAG. In contrast to the air temperature and the $\mathrm{q}_{2 \mathrm{~m}}$, the summer $\mathrm{RH}_{2 \mathrm{~m}}$ (on average higher than $75 \%$ regardless of the NAG phase) changed little during summer over the GrIS. Particularly in the northern regions under +NAG, as the atmosphere has become warmer and moister, less latent heat is consumed to maintain the levels of moisture above the surface. Thus, the vertical mixing of moisture due to stronger winds has gotten less efficient. This is true for most of the northern ablation zone, but not for of the southern part of Greenland. In the lowest part of the GrIS ablation zone and peripheral glaciers, the $\mathrm{RH}_{2 \mathrm{~m}}$ decreased and so did the LHF. Cancelling of positive and negative changes within the ablation zone could have also affected the LHF spatial average. 

upward migration of the snow line (Noël et al., 2019). The air temperature increase is one of the largest changes occurring in the summer accumulation, irrespective of the NAG phase (Fig. S13). This points to a possible increase in the frequency of melt events. Specifically under $+\mathrm{NAG}$, the optical thinning of the atmosphere allows enhanced $\mathrm{SW} \downarrow$ to warm and to darken the surface. As in the ablation zone, and regardless of the NAG phase, SHF has increased in most regions. However, here it is additionally accompanied by considerable increases in $\mathrm{SW}_{\text {net }}$ and decreases in $\mathrm{LW}_{\text {net }}$. $\mathrm{LW}_{\text {net }}$ decreases in the south are related to similar $\mathrm{LW} \uparrow$ fluxes in both periods, while the $\mathrm{LW}_{\text {net }}$ increases in the north are associated with more water vapor in the atmosphere, which then enhances LW $\downarrow$.

In winter, most of the accumulation zone has warmed with respect to 1959-1990 (Fig. S17). The resulting warming bears more water vapor near the surface and at elevated levels of the lower-troposphere over Greenland. Independent of the NAG phase, $\mathrm{LW} \downarrow$ is larger than $\mathrm{LW} \uparrow$ in west Greenland due to a warmer and more humid atmosphere. Consequently, SHF has decreased in identical magnitude in the same regions (Fig. S16a). Under +NAG, the opposite changes occurred in the southeast, especially due to the strengthening of the wind. Except in the north Greenland, overall temperature increases are similar independent of the NAG phase.

\section{Conclusions}

Using the outputs of a regional climate model over the GrIS and adjacent seas, 62 years (1959-2020) of inter-seasonal climate variability were analyzed. A clustering method enabled the Greenland Blocking Index (GBI) and the North Atlantic Oscillation (NAO) to be combined with the integrated water vapor (IWV) into a common classification. This was used for the first time to link pronounced atmospheric blocking conditions over Greenland and the GrIS with pronounced surface pressure gradients in the North Atlantic, in order to describe climate variability. Given the importance of poleward moisture transport on the surface energy fluxes, IWV was also included in the cluster analysis. This helped better separate neutral climate oscillation phases from the rest (since NAO and GBI are often linearly related, and the classification is ambiguous when they are close to zero). The resulting clustering method allowed for characterization of atmospheric circulation patterns that capture the variable influence of the North Atlantic on Greenland, and hence was named NAG. NAG differs from classifications based on seasonal percentile thresholds. While +NAG is associated with low accumulation rates in summer and autumn, +NAG in winter causes high accumulation rates. On average, spring accumulation rates are insensitive to opposing weather patterns.

Inter-seasonal NAG anomalies related to the neutral phase show strong effects for West Greenland, but there are also marked anomalies over the entire GrIS. Larger inter-seasonal differences were found in winter and summer, particularly affecting northern regions. Regional anomalies are found for recent decades compared to 1959-1990 for the three NAG phases. Particularly along the coastline, increased air temperature in winter allows more water vapor in the air, albeit without resulting in saturation. We attribute the increase in near-surface specific humidity and the general tropospheric warming, along with the darkening of the surface, to strongly drive surface heating through enhanced downward longwave radiation. However, the vertically distributed changes in the lower troposphere, i.e., temperature and water vapor changes associated with temperature and humidity 
https://doi.org/10.5194/tc-2021-388

Preprint. Discussion started: 14 January 2022

(c) Author(s) 2022. CC BY 4.0 License.

(c) (i)

inversions and with cloud phases, require further investigation to assess their contribution to the surface warming. Particularly during the cold seasons, when the near-surface radiation deficit is the greatest, and under +NAG conditions, enhanced katabatic winds also contribute to the surface warming.

The factors that have contributed to a higher SEB over the GrIS in recent decades vary across accumulation and ablation zones. The increase of SHF occurs in both zones due to stronger winds and higher temperatures near the surface. However, particularly in the ablation zone, the increases in SHF are similar for contrasting weather patterns, suggesting the influence of drivers beyond the atmospheric configuration. For example, the increased surface pressure gradients between the ablation zones and the adjacent seas, leads us to assume that the decline of sea-ice in recent decades is one such driver, particularly in the north Greenland. However, more investigation is needed to ascertain the specific role of sea-ice concentration in the neighboring seas. An analysis at a higher temporal resolution and of extreme events, would also shed light on the factors behind atmospheric changes and surface melt drivers.

The optical thinning of the lower-troposphere, a characteristic found mainly under $+\mathrm{NAG}$, results in enhanced incoming shortwave radiation, especially over the southern and eastern part of Greenland. In contrast, summer increases in the atmospheric water vapor over the northern accumulation zone are independent of the NAG phase. Despite the water vapor increase in recent decades, there has been relatively little changes in the incoming shortwave radiation over the northern part of Greenland. However, the expansion of the bare ice area has allowed for more absorption of radiation. With respect to the reference period, our results suggest that there have been regional changes in the seasonal impact of key atmospheric circulation patterns on the SEB components. The impact of climate change was found irrespective of the NAG phase examined, which points to an anthropogenic signal beyond the internal climate variability.

Data availability. RACMO2.3p2 (Noël et al., 2019) is available upon contact with Dr. Brice Noël.

Author contributions. TS structured the study; BN and WJB provided the model data; SS acquired the model data; TS did the data analysis; TS, JA, SS, BN, WJB and WS interpreted the results; TS wrote the manuscript with the support of all co-authors.

Competing interests. The authors declare that they have no conflict of interest.

Acknowledgements. The University of Graz is acknowledged for support of publication costs. The authors thank editor Xavier Fettweis for the constructive comments. 
https://doi.org/10.5194/tc-2021-388

Preprint. Discussion started: 14 January 2022

(c) Author(s) 2022. CC BY 4.0 License.

(c) (i)

\section{References}

Athanasiadis, P. J., Yeager, S., Kwon, Y.-O., Bellucci, A., Smith, D. W., and Tibaldi, S.: Decadal predictability of North Atlantic blocking and the NAO, NPJ Climate and Atmospheric Science, 3, 1-10, https://doi.org/10.1038/s41612-020-0120-6, 2020.

Ballinger, T. J., Hanna, E., Hall, R. J., Carr, J. R., Brasher, S., Osterberg, E. C., Cappelen, J., Tedesco, M., Ding, Q., and Mernild, S. H.: The role of blocking circulation and emerging open water feedbacks on Greenland cold-season air temperature variability over the last century, International Journal of Climatology, 41, E2778-E2800, https://doi.org/10.1002/joc.6879, 2021.

Barrett, B. S., Henderson, G. R., McDonnell, E., Henry, M., and Mote, T.: Extreme Greenland blocking and high-latitude moisture transport, Atmospheric Science Letters, 21, e1002, https://doi.org/10.1002/asl.1002, 2020.

Berkelhammer, M., Noone, D. C., Steen-Larsen, H. C., Bailey, A., Cox, C. J., O’Neill, M. S., Schneider, D., Steffen, K., and White, J. W.: Surface-atmosphere decoupling limits accumulation at summit, Greenland, Science Advances, 2, e1501704, https://doi.org/10.1126/sciadv.1501704, 2016.

Bintanja, R.: The impact of Arctic warming on increased rainfall, Scientific reports, 8, 1-6, https://doi.org/10.1038/s41598-018-34450-3, 2018.

Bjørk, A., Aagaard, S., Lütt, A., Khan, S., Box, J., Kjeldsen, K., Larsen, N., Korsgaard, N., Cappelen, J., Colgan, W., et al.: Changes in Greenland's peripheral glaciers linked to the North Atlantic Oscillation, Nature Climate Change, 8, 48-52, https://doi.org/10.1038/s41558017-0029-1, 2018.

Box, J., Fettweis, X., Stroeve, J., Tedesco, M., Hall, D., and Steffen, K.: Greenland ice sheet albedo feedback: thermodynamics and atmospheric drivers, The Cryosphere, 6, 821-839, https://doi.org/10.5194/tc-6-821-2012, 2012.

Broeke, M. R., Enderlin, E. M., Howat, I. M., Kuipers Munneke, P., Noël, B. P., Berg, W. J. v. d., Meijgaard, E. v., and Wouters, B.: On the recent contribution of the Greenland ice sheet to sea level change, The Cryosphere, 10, 1933-1946, https://doi.org/10.5194/tc-10-19332016, 2016.

Cassou, C., Kushnir, Y., Hawkins, E., Pirani, A., Kucharski, F., Kang, I.-S., and Caltabiano, N.: Decadal climate variability and predictability: Challenges and opportunities, Bulletin of the American Meteorological Society, 99, 479-490, https://doi.org/10.1175/BAMS-D-16$0286.1,2018$.

Chatterjee, S., Raj, R. P., Bertino, L., Mernild, S. H., Subeesh, M. P., Murukesh, N., and Ravichandran, M.: Combined influence of oceanic and atmospheric circulations on Greenland sea ice concentration, The Cryosphere, 15, 1307-1319, https://doi.org/10.5194/tc-15-1307$2021,2021$.

420 Davini, P., von Hardenberg, J., and Corti, S.: Tropical origin for the impacts of the Atlantic multidecadal variability on the Euro-Atlantic climate, Environmental Research Letters, 10, 094 010, https://doi.org/10.1088/1748-9326/10/9/094010, 2015.

Ettema, J., Van den Broeke, M., Meijgaard, E. v., Van de Berg, W., Box, J., and Steffen, K.: Climate of the Greenland ice sheet using a high-resolution climate model-Part 1: Evaluation, The Cryosphere, 4, 511-527, https://doi.org/10.5194/tc-4-511-2010, 2010.

Feldstein, S. B.: The dynamics of NAO teleconnection pattern growth and decay, Quarterly Journal of the Royal Meteorological Society: A journal of the atmospheric sciences, applied meteorology and physical oceanography, 129, 901-924, https://doi.org/10.1256/qj.02.76, 2003.

Fettweis, X., Hanna, E., Lang, C., Belleflamme, A., Erpicum, M., and Gallée, H.: Brief communication" Important role of the midtropospheric atmospheric circulation in the recent surface melt increase over the Greenland ice sheet", The Cryosphere, 7, 241-248, https://doi.org/10.5194/tc-7-241-2013, 2013. 
https://doi.org/10.5194/tc-2021-388

Preprint. Discussion started: 14 January 2022

(c) Author(s) 2022. CC BY 4.0 License.

(c) (i)

Fettweis, X., Hofer, S., Krebs-Kanzow, U., Amory, C., Aoki, T., Berends, C. J., Born, A., Box, J. E., Delhasse, A., Fujita, K., et al.: GrSMBMIP: Intercomparison of the modelled 1980-2012 surface mass balance over the Greenland Ice sheet, The Cryosphere, 14, 3935-3958, https://doi.org/10.5194/tc-14-3935-2020, 2020.

Gregory, J. M., George, S. E., and Smith, R. S.: Large and irreversible future decline of the Greenland ice sheet, The Cryosphere, 14, 4299-4322, https://doi.org/10.5194/tc-14-4299-2020, 2020.

Hahn, L. C., Armour, K. C., Battisti, D. S., Eisenman, I., and Bitz, C. M.: Seasonality in Arctic Warming Driven By Sea Ice Effective Heat Capacity, Journal of Climate, pp. 1-44, https://doi.org/10.1175/JCLI-D-21-0626.1, 2021.

Hanna, E., Jones, J. M., Cappelen, J., Mernild, S. H., Wood, L., Steffen, K., and Huybrechts, P.: The influence of North Atlantic atmospheric and oceanic forcing effects on 1900-2010 Greenland summer climate and ice melt/runoff, International Journal of Climatology, 33, 862880, https://doi.org/10.1002/joc.3475, 2013.

Hanna, E., Cropper, T. E., Jones, P. D., Scaife, A. A., and Allan, R.: Recent seasonal asymmetric changes in the NAO (a marked summer decline and increased winter variability) and associated changes in the AO and Greenland Blocking Index, International Journal of Climatology, 35, 2540-2554, https://doi.org/10.1002/joc.4157, 2015.

Hanna, E., Cropper, T. E., Hall, R. J., and Cappelen, J.: Greenland Blocking Index 1851-2015: a regional climate change signal, International Journal of Climatology, 36, 4847-4861, https://doi.org/10.1002/joc.4673, 2016.

Hanna, E., Cappelen, J., Fettweis, X., Mernild, S. H., Mote, T. L., Mottram, R., Steffen, K., Ballinger, T. J., and Hall, R. J.: Greenland surface air temperature changes from 1981 to 2019 and implications for ice-sheet melt and mass-balance change, International Journal of Climatology, 41, E1336-E1352, https://doi.org/10.1002/joc.6771, 2021.

Hermann, M., Papritz, L., and Wernli, H.: A Lagrangian Analysis of the Dynamical and Thermodynamic Drivers of Greenland Melt Events during 1979-2017, Weather and Climate Dynamics Discussions, pp. 1-32, https://doi.org/10.5194/wcd-2020-16, 2020.

Hofer, S., Tedstone, A. J., Fettweis, X., and Bamber, J. L.: Decreasing cloud cover drives the recent mass loss on the Greenland Ice Sheet, Science Advances, 3, e1700 584, https://doi.org/10.1126/sciadv.1700584, 2017.

Huai, B., van den Broeke, M. R., and Reijmer, C. H.: Long-term surface energy balance of the western Greenland Ice Sheet and the role of large-scale circulation variability, The Cryosphere, 14, 4181-4199, https://doi.org/10.5194/tc-14-4181-2020, 2020.

Hurrell, J. W., Kushnir, Y., Ottersen, G., and Visbeck, M.: An overview of the North Atlantic oscillation, Geophysical Monograph-American Geophysical Union, 134, 1-36, https://doi.org/10.1029/134GM01, 2003.

Lenaerts, J. T., Gettelman, A., Van Tricht, K., van Kampenhout, L., and Miller, N. B.: Impact of cloud physics on the Greenland ice sheet Near-Surface climate: A study with the Community Atmosphere Model, Journal of Geophysical Research: Atmospheres, 125, https://doi.org/10.1029/2019JD031470, 2020.

Lim, Y.-K., Schubert, S. D., Nowicki, S. M., Lee, J. N., Molod, A. M., Cullather, R. I., Zhao, B., and Velicogna, I.: Atmospheric summer teleconnections and Greenland Ice Sheet surface mass variations: Insights from MERRA-2, Environmental Research Letters, 11, 024002 , https://doi.org/10.1088/1748-9326/11/2/024002, 2016.

MacFerrin, M., Machguth, H., van As, D., Charalampidis, C., Stevens, C. M., Heilig, A., Vandecrux, B., Langen, P. L., Mottram, R., Fettweis, X., et al.: Rapid expansion of Greenland's low-permeability ice slabs, Nature, 573, 403-407, https://doi.org/10.1038/s41586-019-1550-3, 2019.

Mankoff, K. D., Noël, B., Fettweis, X., Ahlstrøm, A. P., Colgan, W., Kondo, K., Langley, K., Sugiyama, S., van As, D., and Fausto, R. S.: Greenland liquid water discharge from 1958 through 2019, Earth System Science Data, 12, 2811-2841, https://doi.org/10.5194/essd-122811-2020, 2020. 
https://doi.org/10.5194/tc-2021-388

Preprint. Discussion started: 14 January 2022

(c) Author(s) 2022. CC BY 4.0 License.

(c) (i)

Martineau, P., Nakamura, H., Kosaka, Y., and Yamamoto, A.: Importance of a vertically tilting structure for energizing the North Atlantic Oscillation, Scientific reports, 10, 1-10, https://doi.org/10.1038/s41598-020-69551-5, 2020.

Mouginot, J., Rignot, E., Bjørk, A. A., Van den Broeke, M., Millan, R., Morlighem, M., Noël, B., Scheuchl, B., and Wood, M.: Forty-six years of Greenland Ice Sheet mass balance from 1972 to 2018, Proceedings of the National Academy of Sciences, 116, 9239-9244, https://doi.org/10.1073/pnas.1904242116, 2019.

Myers, P. G., Castro de la Guardia, L., Fu, C., Gillard, L. C., Grivault, N., Hu, X., Lee, C. M., Moore, G., Pennelly, C., Ribergaard, M. H., et al.: Extreme High Greenland Blocking Index Leads to the Reversal of Davis and Nares Strait Net Transport Towards the Arctic Ocean, Geophysical Research Letters, p. e2021GL094178, https://doi.org/10.1029/2021GL094178, 2021.

Niwano, M., Hashimoto, A., and Aoki, T.: Cloud-driven modulations of Greenland ice sheet surface melt, Scientific reports, 9, 1-8, https://doi.org/10.1038/s41598-019-46152-5, 2019.

Niwano, M., Box, J., Wehrlé, A., Vandecrux, B., Colgan, W., and Cappelen, J.: Rainfall on the Greenland ice sheet: present-day climatology from a high-resolution non-hydrostatic polar regional climate model, Geophysical Research Letters, p. e2021GL092942, 2021.

Noël, B., Van De Berg, W., Van Meijgaard, E., Kuipers Munneke, P., Van De Wal, R., and Van Den Broeke, M.: Evaluation of the updated regional climate model RACMO2. 3: summer snowfall impact on the Greenland Ice Sheet, The Cryosphere, 9, 1831-1844, https://doi.org/10.5194/tc-9-1831-2015, 2015.

Noël, B., Van de Berg, W., Lhermitte, S., Wouters, B., Machguth, H., Howat, I., Citterio, M., Moholdt, G., Lenaerts, J., and van den Broeke, M. R.: A tipping point in refreezing accelerates mass loss of Greenland's glaciers and ice caps, Nature Communications, 8 , 1-8, https://doi.org/10.1038/ncomms14730, 2017.

Noël, B., Berg, W. J. v. d., Wessem, J., Meijgaard, E. v., As, D. v., Lenaerts, J., Lhermitte, S., Kuipers Munneke, P., Smeets, C., Ulft, L. H. v., et al.: Modelling the climate and surface mass balance of polar ice sheets using RACMO2-Part 1: Greenland (1958-2016), The Cryosphere, 12, 811-831, https://doi.org/10.5194/tc-12-811-2018, 2018.

Noël, B., van de Berg, W. J., Lhermitte, S., and van den Broeke, M. R.: Rapid ablation zone expansion amplifies north Greenland mass loss, Science advances, 5, eaaw0123, https://doi.org/10.1126/sciadv.aaw0123, 2019.

Oltmanns, M., Straneo, F., and Tedesco, M.: Increased Greenland melt triggered by large-scale, year-round cyclonic moisture intrusions, The Cryosphere, 13, 815-825, https://doi.org/10.5194/tc-13-815-2019, 2019.

Papritz, L., Hauswirth, D., and Hartmuth, K.: Moisture origin, transport pathways, and driving processes of intense wintertime moisture transport into the Arctic, Weather and Climate Dynamics Discussions, pp. 1-32, https://doi.org/10.5194/wcd-2021-57, 2021.

Pedersen, R. A. and Christensen, J. H.: Attributing Greenland warming patterns to regional Arctic sea ice loss, Geophysical Research Letters, 46, 10 495-10 503, https://doi.org/10.1029/2019GL083828, 2019.

Reusen, J., van der Linden, E., and Bintanja, R.: Differences between Arctic interannual and decadal variability across climate states, Journal of Climate, 32, 6035-6050, https://doi.org/10.1175/JCLI-D-18-0672.1, 2019.

Ruprich-Robert, Y., Msadek, R., Castruccio, F., Yeager, S., Delworth, T., and Danabasoglu, G.: Assessing the climate impacts of the observed Atlantic multidecadal variability using the GFDL CM2. 1 and NCAR CESM1 global coupled models, Journal of Climate, 30, 2785-2810, https://doi.org/10.1175/JCLI-D-16-0127.1, 2017.

Ryan, J., Smith, L., Van As, D., Cooley, S., Cooper, M., Pitcher, L., and Hubbard, A.: Greenland Ice Sheet surface melt amplified by snowline migration and bare ice exposure, Science Advances, 5, eaav3738, https://doi.org/10.1126/sciadv.aav3738, 2019.

Shahi, S., Abermann, J., Heinrich, G., Prinz, R., and Schöner, W.: Regional variability and trends of temperature inversions in Greenland, Journal of Climate, 33, 9391-9407, https://doi.org/10.1175/JCLI-D-19-0962.1, 2020. 
https://doi.org/10.5194/tc-2021-388

Preprint. Discussion started: 14 January 2022

(c) Author(s) 2022. CC BY 4.0 License.

(c) (i)

Shepherd, A., Ivins, E., Rignot, E., Smith, B., Van Den Broeke, M., Velicogna, I., Whitehouse, P., Briggs, K., Joughin, I., Krinner, G., et al.: Mass balance of the Greenland Ice Sheet from 1992 to 2018, Nature, 579, 233-239, https://doi.org/10.1038/s41586-019-1855-2, 2020.

Tedesco, M. and Fettweis, X.: Unprecedented atmospheric conditions (1948-2019) drive the 2019 exceptional melting season over the Greenland ice sheet, The Cryosphere, 14, 1209-1223, https://doi.org/10.5194/tc-14-1209-2020, 2020.

510 Tedesco, M., Mote, T., Fettweis, X., Hanna, E., Jeyaratnam, J., Booth, J. F., Datta, R., and Briggs, K.: Arctic cut-off high drives the poleward shift of a new Greenland melting record, Nature Communications, 7, 1-6, https://doi.org/10.1038/ncomms11723, 2016.

Uppala, S. M., Kållberg, P., Simmons, A., Andrae, U., Bechtold, V. D. C., Fiorino, M., Gibson, J., Haseler, J., Hernandez, A., Kelly, G., et al.: The ERA-40 re-analysis, Quarterly Journal of the Royal Meteorological Society: A journal of the atmospheric sciences, applied meteorology and physical oceanography, 131, 2961-3012, https://doi.org/10.1256/qj.04.176, 2005.

Valkonen, E., Cassano, J., and Cassano, E.: Arctic Cyclones and Their Interactions with the Declining Sea Ice: A Recent Climatology, Journal of Geophysical Research: Atmospheres, p. e2020JD034366, https://doi.org/10.1029/2020JD034366, 2021.

Van Angelen, J., Lenaerts, J., Lhermitte, S., Fettweis, X., Kuipers Munneke, P., Van den Broeke, M., Meijgaard, E. v., and Smeets, C.: Sensitivity of Greenland Ice Sheet surface mass balance to surface albedo parameterization: a study with a regional climate model, The Cryosphere, 6, 1175-1186, https://doi.org/10.5194/tc-6-1175-2012, 2012.

van Meijgaard, E., Van Ulft, L., Van de Berg, W., Bosveld, F., Van den Hurk, B., Lenderink, G., and Siebesma, A.: The KNMI regional atmospheric climate model RACMO, version 2.1, KNMI De Bilt, Netherlands, https://cdn.knmi.nl/knmi/pdf/bibliotheek/knmipubTR/ TR302.pdf, 2008.

Wang, W., Zender, C. S., van As, D., Fausto, R. S., and Laffin, M. K.: Greenland surface melt dominated by solar and sensible heating, Geophysical Research Letters, 48, e2020GL090 653, https://doi.org/10.1029/2020GL090653, 2021.

Wang, Y., Sugiyama, S., and Bjørk, A. A.: Surface Elevation Change of Glaciers Along the Coast of Prudhoe Land, Northwestern Greenland from 1985 to 2018, Journal of Geophysical Research: Earth Surface, p. e2020JF006038, https://doi.org/10.1029/2020JF006038, 2021.

Woollings, T., Barriopedro, D., Methven, J., Son, S.-W., Martius, O., Harvey, B., Sillmann, J., Lupo, A. R., and Seneviratne, S.: Blocking and its response to climate change, Current climate change reports, 4, 287-300, https://doi.org/0.1007/s40641-018-0108-z, 2018.

Zou, F., Tenzer, R., Fok, H. S., and Nichol, J. E.: Mass balance of the greenland ice sheet from GRACE and surface mass balance modelling, Water, 12, 1847, https://doi.org/10.3390/w12071847, 2020. 